\title{
Penerapan Strategi Pemecahan Masalah Sistematis (Systematic Approach to Problem Solving) untuk Meningkatkan Hasil Belajar Matematika Kelas XI IPS 2 SMA Negeri 1 Kerinci Tahun Pelajaran 2019/2020
}

\author{
Hadiawati \\ SMA Negeri 1 Kerinci \\ Correspondence email: hadiawati76@gmail.com
}

\begin{abstract}
Abstrak. Penelitian ini bernama penelitian tindakan kelas, Penelitian ini dilakukan karena banyak ditemui hasil belajar siswa di bawah batas ketuntasan minimal, oleh karena itu penulis mencoba untuk meningkatkan hasil belajar matematika dengan menerapkan model pembelajaran Strategi Pemecahan Masalah Sistematis. Penelitian ini bertujuan untuk meningkatkan pemahaman siswa pada materi pelajaran Limit Fungsi Aljabar sehingga hasil belajar siswa meningkat secara signifikan. Subjek penelitian adalah siswa kelas XI IPS 2 SMAN 1 Kerinci. Penelitian ini dibantu oleh rekan sesama guru mata pelajaran matematika yang berperan sebagai kolaborator. Penelitian dilakukan sebanyak dua siklus dimana setiap siklus terdiri dari empat tahapan yaitu (a) Perencanaan (b) Pelaksanaan (c) Observasi (d) Refleksi. Hasil analisis data, ketuntasan hasil belajar mate matika pada siklus 1 dengan rata-rata nilai 69 atau $65 \%$. Pada siklus 2 menunjukkan peningkatan dengan pencapai ketuntasan 83 atau 85\%. Peningkatan terjadi secara signifikan pada siklus 2. Sehingga dapat disimpulkan bahwa terjadi peningkatan hasil belajar siswa setelah dilakukan penerapan model pembelajaran Strategi Pemecahan Masalah Sistematis pada pokok bahasan Limit fungsi aljabar di kelas XI IPS 2 SMAN 1 Kerinci. Oleh karena itu disarankan kepada guru mata pelajaran matematika agar menggunakan model pembelajaran Strategi Pemecahan Masalah Sistematis sebagai salah satu solusi untuk mengatasi permasalahan dalam belajar matematika terutama pada materi Limit Fungsi Aljabar.
\end{abstract}

Kata Kunci: Strategi Pemecahan Masalah Sistematis; Hasil Belajar

Abstract. This study was an Action Research which was conducted because the student's achievement on Mathematics were still lower than The Minimum Achievement Criteria (KKM). The research was conducted to see whether the Systematic Problem Solving Strategy could improve the student's learning achievement. The aim of the research was to improve the student's comprehension on Algebra Limit Function subject In Mathematics, so their learning achievement also improved significantly. The research participants were the students of grade XI IPS 2 SMAN 1 Kerinci. The researcher was helped by a collaborator who was a Math Teacher at the same school. The study was done in two cycles with four stages, (a) Planning (b) Action (c) Observation (d) Reflection. The result of data analysis showed that the student's average score in cycle 1 was 69 (65\%). It became higher in cyle 2 to 83 ( $85 \%)$. There was significant improvement seen from the result of cycle 1 compared to cycle 2. It could be concluded that the implementation of Systematic Problem Solving Strategy on Algebra Limit Function subject improved the student's learning achievement significantly. Therefore, it was suggested to Math Teachers to apply the strategy in teaching as the alternative solution particularly in Algebra Limit Function subject

Keywords: Systematic Problem Solving Strategies; Learning Outcomes

\section{PENDAHULUAN}

Belajar adalah proses perubahan perilaku berkat pengalaman dan pelatihan. Artinya belajar adalah proses perubahan tingkah laku, baik yang menyangkut pengetahuan, keterampilan, sikap bahkan meliputi segenap aspek pribadi. Menurut Slameto (2003) belajar adalah proses usaha yang dilakukan seseorang untuk memperoleh perubahan tingkah laku yang baru secara keseluruhan, sebagai hasil pengalamannya sendiri setelah berinteraksi dengan lingkungannya.

Sejalan dengan pendapat tentang belajar, Hilgard dalam Wina Sanjaya (2005) mengatakan bahwa belajar adalah proses perubahan melalui kegiatan atau prosedur latihan baik latihan di dalam laboratorium maupun dalam lingkungan alamiah.

Dengan demikian belajar adalah proses perubahan ke arah yang lebih baik atau dari tidak tahu menjadi tahu terhadap ilmu pengetahuan, kecakapan hidup, keterampilan, sikap dan berbagai aspek kehidupan lainnya yang menyangkut hasil dari proses belajar.

Proses pembelajaran yang baik akan membuahkan hasil belajar yang maksimal. Sebagaimana yang dikatakan oleh Mulyasa (2004) bahwa hasil belajar bergantung pada cara-cara belajar yang dipergunakan. Jadi, cara belajar yang efektif dan efisien akan dapat meningkatkan hasil belajar. Hasil belajar itu sendiri adalah kemampuan yang diperoleh siswa setelah melalui kegiatan belajar. Menurut Nana Sudjana (2008) hasil belajar adalah penguasaan yang dicapai oleh siswa dalam mengikuti proses belajar mengajar dengan tujuan pendidikan yang telah ditetapkan sebelumnya.Selanjutnya Ahmad Sabri (2007) berpendapat bahwa hasil belajar merupakan salah satu yang dapat mencerminkan sudah sejauh mana tercapai tujuan pembelajaran yang diharapkan.

Dari beberapa pendapat para ahli pendidikan 
mengenai pengertian hasil belajar yang telah dikemukakan, penulis dapat mengartikannya bahwa hasil belajar adalah kemampuan yang dimiliki oleh siswa setelah mengikuti proses belajar mengajar yang dapat mencerminkan penilaian terhadap tujuan pembelajaran yang telah ditetapkan.

Dalam proses pembelajaran, guru dituntut menguasai keterampilan dalam memilih strategi dan metode yang digunakan. Tanpa strategi yang jelas, proses pembelajaran tidak akan terarah, sehingga tujuan pembelajaran yang telah ditetapkan sulit tercapai secara optimal, dengan kata lain pembelajaran tidak berlangsung secara efektif dan efisien. Oleh karena itu, guru perlu menguasai dan dapat menerapkan berbagai strategi yang di dalamnya terdapat pendekatan, model, dan tehnik secara spesifik.

Mengingat pentingnya peranan matematika dalam kehidupan dan Ilmu Pengetahuan dan Teknologi (IPTEK), maka salah satu cara untuk mencapai tujuan yang diharapkan dari matematika itu adalah dengan meningkatkan hasil belajar matematika siswa disetiap jenjang pendidikan. Selanjutnya menurut Cokroft dalam Mulyono Abdurrahman (2003) bahwa alasan pentingnya mempelajari matematika sebagai berikut: (a). Selalu digunakan dalam segala kehidupan. (b). Semua bidang studi memerlukan keterampilan yang sesuai. (c). Merupakan sarana komunikasi yang kuat, singkat, dan jelas. (d). Dapat digunakan untuk menyajikan informasi dalam berbagai cara (e). Meningkatkan berfikir logis, ketelitian, dan kesadaran keruangan. (f). Memberikan kepuasan terhadap usaha memecahkan masalah yang menantang.

Hasil belajar merupakan penguasaan yang dicapai oleh siswa dalam mengikuti proses belajar mengajar dengan tujuan pendidikan yang telah ditetapkan sebelumnya.

Berdasarkan hasil Ulangan harian siswa kelas XI IPS 2 sebelum dilakukan tindakan nilai yang diperoleh siswa masih rendah. Ini ditandai dengan hal-hal sebagai berikut:

1. Hasil belajar matematika siswa secara klasikal masih rendah, ketuntasannya rata-rata di bawah $60 \%$, sedangkan Standar Kriteria Ketuntasan Minimal (KKM) adalah $\geq 70$.

2. Hanya sebagian siswa yang dapat mengerjakan dengan benar. Hal ini dibuktikan ketika lembar jawaban diperiksa hanya sedikit siswa yang dapat menjawab dengan benar, sehingga banyak siswa remedial karena hasil belajar yang masih rendah

3. Bila guru memberikan pekerjaan rumah yang sedikit berbeda dari contoh, banyak siswa yang kurang paham menyelesaikannya.

Dari masalah-masalah yang telah dikemukakan, perlu adanya antisipasi dengan cara mencari solusi yang tepat supaya tujuan dari pembelajaran dapat tercapai. Akan tetapi jika hal ini dibiarkan begitu saja, maka tujuan dari pembelajaran tidak akan tercapai secara optimal.

Menurut Gagne dalam Made Wena (2009) bahwa cara terbaik yang dapat membantu siswa dalam memecahkan masalah adalah memecahkan masalah selangkah demi selangkah dengan menggunakan aturan tertentu. Selanjutnya Kennedy (dalam Mulyono Abdurrahman (2003) menyarankan empat langkah proses pemecahan masalah matematika, yaitu: (a). Memahami masalah (b). Merencanakan pemecahan masalah (c). Melaksanakan pemecahan masalah. d). Memeriksa kembali, mengecek hasilnya

Beranjak dari pendapat para ahli mengenai teori dan keunggulan dari strategi pemecahan masalah sistematis, maka penulis menerapkan strategi pemecahan masalah sistematis pada pokok bahasan Limit Fungsi untuk meningkatkan hasil belajar matematika siswa kelas XI IPS 2 SMA Negeri 1 Kerinci.

Dari beberapa keunggulan strategi pemecahan masalah sistematis yang telah disebutkan sebelumnya, maka strategi pemecahan masalah sistematis mampu memberikan solusi dalam memecahkan masalah sehingga dapat meningkatkan hasil belajar matematika siswa.

Agar penelitian ini lebih terarah maka peneliti merumuskan masalah penelitian ini yaitu "Bagaimanakah penerapan strategi pemecahan masalah sistematis dapat meningkatkan hasil belajar matematika siswa kelas XI IPS 2 SMA Negeri 1 Kerinci pada pokok bahasan Limit Fungsi Aljabar?"

Oleh sebab itu, penulis melakukan penelitian dengan menerapkan strategi pemecahan masalah sistematis untuk meningkatkan hasil belajar matematika siswa Strategi Pemecahan Masalah Sistematis.

Untuk menghasilkan siswa yang memiliki kompetensi, maka salah satu yang diperlukan yaitu serangkaian strategi pembelajaran pemecahan masalah. Berdasarkan kajian beberapa literatur terdapat banyak strategi pemecahan masalah yang dapat diterapkan dalam pembelajaran. Salah satu strategi pemecahan masalah yang penulis gunakan adalah strategi pemecahan masalah sistematis.

Menurut Made Wena (2009) bahwa strategi pemecahan masalah sistematis adalah petunjuk untuk melakukan suatu tindakan yang berfungsi untuk membantu seseorang dalam menyelesaikan suatu permasalahan. Salah satu sumber lain mengatakan bahwa strategi pemecahan masalah sistematis adalah sebuah pendekatan langkah demi langkah untuk mengatasi masalah atau isu.

Berdasarkan pendapat para ahli mengenai pengertian strategi pemecahan masalah tersebut, penulis dapat mengartikan bahwa strategi pemecahan masalah sistematis adalah strategi yang dapat membantu siswa dalam menyelesaikan masalah secara bertahap dengan aturan tertentu. 
Hadiawati, Penerapan Strategi Pemecahan Masalah Sistematis (Systematic Approach to Problem Solving) untuk Meningkatkan Hasil Belajar Matematika Kelas XI IPS 2 SMA Negeri 1 Kerinci Tahun Pelajaran 2019/2020

Tabel 1. Langkah-langkah Penggunaan Strategi Pemecahan Masalah Sistematis

\begin{tabular}{|c|c|c|c|c|}
\hline No & Tahap Pembelajaran & Tujuan & Kegiatan Guru & Kegiatan Siswa \\
\hline 1. & Analisis soal & $\begin{array}{l}\text { Memperoleh } \\
\text { gambaran yang } \\
\text { menyeluruh tentang } \\
\text { data yang diketahui } \\
\text { dan besaran yang } \\
\text { tidak diketahui }\end{array}$ & $\begin{array}{l}\text { Membimbing } \\
\text { siswa secara } \\
\text { bertahap untuk } \\
\text { melakukan } \\
\text { analisis soal }\end{array}$ & $\begin{array}{l}\text { Membaca seluruh soal yang diberikan secara } \\
\text { seksama } \\
\text { Mentransformasi soal ke bentuk skema yang } \\
\text { menggambarkan situasi soal } \\
\text { Memperkirakan jawaban (tanda, besaran, dan } \\
\text { dimensi) }\end{array}$ \\
\hline 2. & Transformasi soal & $\begin{array}{l}\text { Mengubah soal ke } \\
\text { bentuk standar }\end{array}$ & $\begin{array}{l}\text { Membimbing } \\
\text { siswa } \\
\text { melakukan } \\
\text { transformasi } \\
\text { soal }\end{array}$ & $\begin{array}{l}\text { Mengecek apakah soalnya sudah berbentuk } \\
\text { standar? Jika ya lanjutkan ke fase } 3 \text {, jika tidak, } \\
\text { ikuti langkah selanjutnya }\end{array}$ \\
\hline & & & & $\begin{array}{l}\text { Mengubah soal ke bentuk standar: } \\
\text { Menulis rumus yang memuat besaran yang } \\
\text { ditanyakan. Apabila dalam rumus tersebut ada } \\
\text { besaran yang tidak diketahui selain besaran yang } \\
\text { ditanyakan maka substitusikan besaran yang tidak } \\
\text { diketahui itu dengan rumus lain sehingga terbentuk } \\
\text { rumus baru. Demikian seterusnya hingga diperoleh } \\
\text { bentuk standar Jika dengan langkah di atas belum } \\
\text { diperoleh bentuk standar, dapat dilakukan dengan } \\
\text { menyederhanakan soal dengan asumsi-asumsi atau } \\
\text { dengan meninjau soal dari titik pandang yang } \\
\text { berbeda. }\end{array}$ \\
\hline 3. & Operasi perhitungan & $\begin{array}{l}\text { Memperoleh } \\
\text { jawaban soal }\end{array}$ & $\begin{array}{l}\text { Membimbing } \\
\text { siswa } \\
\text { melakukan } \\
\text { operasi hitungan }\end{array}$ & $\begin{array}{l}\text { Mensubtitusikan data yang diketahi ke dalam } \\
\text { bentuk standar yang telah diperoleh, kemudian } \\
\text { melakukan perhitungan } \\
\text { Mengecek apakah tanda dan satuan sudah Sesuai? }\end{array}$ \\
\hline 4. & $\begin{array}{l}\text { Pengecekan dan } \\
\text { interpretasi }\end{array}$ & $\begin{array}{l}\text { Mengecek apakah } \\
\text { soal sudah } \\
\text { diselesaikan dengan } \\
\text { benar dan lengkap }\end{array}$ & $\begin{array}{l}\text { Membimbing } \\
\text { siswa melakukan } \\
\text { pengecekan } \\
\text { terhadap hasil } \\
\text { penyelesaian soal }\end{array}$ & $\begin{array}{l}\text { Mengecek jawaban dengan cara membandingkan } \\
\text { dengan perkiraan jawaban yang dibuat pada fase } \\
1 \\
\text { Mengecek apakah jawaban sudah sesuai dengan } \\
\text { yang ditanyakan? } \\
\text { Menelusuri kesalahan-kesalahan apa yang telah } \\
\text { dilakukan }\end{array}$ \\
\hline
\end{tabular}

Sumber: Made Wena, Strategi Pembelajaran Inovatif Kontemporer, Bumi Aksara, Jakarta, 2009

Hasil pembelajaran pada strategi pemecahan masalah sistematis didapat dari beberapa langkah, namun untuk memperoleh pengetahuan prosedural menurut Dahar dalam Made Wena (2009) bahwa dibutuhkan latihan-latihan dan umpan balik.

Dengan pemecahan masalah sistematis, siswa tidak hanya mengetahui apa yang diketahui, apa yang ditanyakan, tetapi juga dilatih menganalisis soal, mengetahui secara pasti situasi soal, besaran yang diketahui dan yang ditanyakan serta perkiraan jawaban soal.

\section{METODE}

\section{Subjek Penelitian}

Subjek pada penelitian ini adalah seluruh siswa pada kelas XI IPS 2, yang berjumlah 20 siswa yang terdiri dari 8 siswa laki-laki dan 12 siswa perempuan. Sedangkan objeknya adalah hasil belajar matematika dan penerapan strategi pemecahan masalah sistematis.

\section{Waktu Penelitian}

Penelitian dilaksanakan Pada tanggal 02 Januari s.d 31 Maret 2020, pada mata pelajaran Matematika dengan materi Limit fungsi aljabar di semester genap tahun pelajaran 2019/2020.

\section{Tempat Penelitian}

Penelitian dilaksanakan di SMA Negeri 1 Kerinci yang terletak di desa hiang lestari kecamatan sitinju laut

\section{RancanganPenelitian}

Bentuk penelitiana adalah Penelitian Tindakan Kelas (PTK). PTK merupakan penelitian yang dilaksanakan oleh guru bidang studi di kelas. yang bertujuan untuk memperbaiki kinerja sebagai seorang guru, sehingga hasil belajar siswa semakin meningkat. dengan guru menerapkan strategi pemecahan masalah sistematis dan mengamati hasil akhir penelitian sebagai hasil belajar siswa. Adapun langkah-langkah dalam PTK yang dimaksud di sini adalah

\section{Perencanaan}

Pada tahap perencanaan, dipersiapkan segala sesuatu yang dibutuhkan dalam pelaksanaan penelitian, 
diantaranya:

a) Memilih pokok bahasannya yaitu limit fungsi, karena materi ini cocok untuk strategi yang digunakan pada penelitian dan dapat meningkatkan hasil belajar matematika siswa.

b) Menetapkan standar kompetensi dan indikator dalam pembelajaran pada materi yang dipelajari.

c) Menyusun Rencana Pelaksanaan Pembelajaran (RPP)

d) Membuat soal-soal tes

e) Membuat lembar observasi kegiatan guru dan siswa dengan penerapan strategi pemecahan masalah sistematis.

\section{Pelaksanaan}

Tahap tindakan yang dilaksanakan dalam kegiatan belajar dengan menggunakan strategi pemecahan masalah sistematis adalah sebagai berikut:

a) Memahami masalahnya

Guru membimbing siswa secara bertahap untuk melakukan analisis soal. Selanjutnya kegiatan siswa membaca seluruh soal yang diberikan secara seksama. Adapun tujuannya yaitu memperoleh gambaran yang menyeluruh tentang data yang diketahui dan yang tidak diketahui.

b) Membuat rencana penyelesaian

Guru membimbing siswa untuk melakukan transformasi soal dan siswa mengecek, apakah soalnya sudah berbentuk standar atau belum. Jika dilanjutkan kefase 3, jika tidak ikuti langkah selanjutnya. Tujuannya untuk mengubah soal kebentuk standar.

c) Melaksanakan rencana penyelesaian

Pada tahap melaksanakan rencana penyelesaian, yang dilakukan guru yaitu membimbing siswa melakukan operasi hitungan, yang mana kegiatan siswa mensubstitusikan data yang sudah diketahui kedalam bentuk standar yang telah diperoleh, kemudian melakukan perhitungan. Tujuannya untuk memperoleh jawaban soal.

d) Memeriksa kembali, mengecek hasilnya

Guru membimbing siswa melakukan pengecekan terhadap hasil penyelesaian soal. Misalnya mengecek apakah jawaban sudah sesuai dengan yang ditanyakan serta menelusuri kesalahan- kesalahan apa yang telah dilakukan. Tujuannya untuk mengecek apakah soal sudah diselesaikan dengan benar dan lengkap.

\section{Observasi}

Observasi yang dilakukan adalah proses pengamatan terhadap pelaksanaan pembelajaran matematika dengan menggunakan strategi pemecahan masalah sistematis. Observasi ini dilakukan pada saat proses pembelajaran dimulai dengan menggunakan lembaran observasi guru dan siswa untuk mengamati kegiatan guru dan siswa selama proses pembelajaran berlangsung. Pemberian soal postest dilaksanakan setiap siklus untuk mengetahui peningkatan hasil belajar matematika yang dicapai siswa.

\section{Refleksi}

Setelah data dikumpulkan pada siklus I, data tersebut dianalisis oleh guru bersama observer, kelemahan-kelemahan yang terjadi pada siklus I ditetapkan tindakannya untuk mengatasi kekurangan pada siklus berikutnya. Tujuan yang dicapai pada pelaksanaan tiap siklus adalah hasil belajar matematika siswa mencapai KKM dan target yang diharapkan dalam penelitian, baik secara individual maupun klasikal.

\section{Jenis Instrumen Pengumpulan Data}

a) Tes menggunakan instrumen soal essay untuk mengukur kemampuan hasil belajar siswa.

b) Observasi

Menggunakan lembaran observasi untuk mengukur hasil guru dalam proses pelaksanaan belajar matematika. Adapun kegiatan guru yang diamati antara lain guru menjelaskan kompetensi dasar dan indikator yang harus dicapai oleh siswa. Guru menginformasikan materi, strategi pembelajaran dan tugas- tugas yang akan dikerjakan siswa dalam pembelajaran, memotivasi siswa dalam melakukan kegiatan pembelajaran, membimbing siswa untuk menyelesaikan masalah, menentukan nilai individual, menyimpulkan dan menutup pelajaran.

c) Data tentang hasil belajar sebelum dilakukan tindakan.

\section{Teknik pengumpulan data}

Data hasil belajar siswa sebelum tindakan diperoleh dari data hasil pretest materi limit fungsi, sedangkan data setelah tindakan diperoleh dari nilai post test hasil belajar siswa setelah mengikuti pembelajaran dengan strategi pemecahan masalah sistematis pada materi limit fungsi dengan topik. Menentukan Limit Fungsi Aljabar $\mathrm{f}(\mathrm{x})=\mathrm{a}, \quad$ Menentukan Limit fungsi Aljabar $\mathrm{f}(\mathrm{x})=\sim$ teorema Limit.

\section{Teknik analisis data}

Teknik analisis data yang digunakan adalah analisis deskriptif, yaitu memaparkan data hasil pengamatan tiap akhir siklus. Tujuannya untuk melihat tingkat ketuntasan belajar siswa baik secara individual maupun klasikal. Adapun persamaan yang digunakan adalah sebagai berikut:

a) Ketuntasan individual dengan rumus:

$$
\mathrm{S}=\frac{R}{N} \times 100 \%
$$

\section{Keterangan:}

$\mathrm{S}=$ Persentase ketuntasan individual

$\mathrm{R}=$ Skor yang diperoleh siswa

$\mathrm{N}=$ Skor maksimum tes Ketuntasan individual

Tercapai jika $\square 75 \%$ 
b) Ketuntasan belajar klasikal dengan rumus:

$$
\begin{aligned}
& \mathrm{P}=\frac{R}{T} \times 100 \% \\
& \text { Keterangan: } \\
& \mathrm{P} \quad=\text { persentase ketuntasan klasikal } \\
& \mathrm{R} \quad=\text { jumlah siswa yang tuntas } \\
& \mathrm{T} \quad=\text { jumlah seluruh siswa Ketuntasan klasikal } \\
& \text { tercapai jika }
\end{aligned}
$$

\section{HASIL DAN PEMBAHASAN}

\section{Pembelajaran Awal (Pra Tindakan)}

Pembelajaran pra tindakan yang dimaksud adalah pembelajaran tanpa menggunakan strategi pemecahan masalah sistematis. Data mengenai hasil belajar matematika siswa pada pra tindakan adalah hasil pretest untuk mengetahui kemampuan awal siswa sebelum masuk pada siklus I, guru membagikan soal pretest ke siswa untuk dikerjakan selama 10 menit dan dikumpulkan jawabannya. Dari hasil pretest matematika siswa pada pra tindakan, tampaklah bahwa hanya 7 siswa yang tuntas mengerjakan soal pretest dari 20 orang jumlah siswa kelas XI IPS 2 dengan nilai rata-rata ketuntasan 44,85. Hasil ini masih sangat tergolong rendah, secara klasikal presentase ketuntasannya baru mencapai $35 \%$.

Jadi, hasil pretest matematika tersebut jelaslah belum mencapai target peneliti. maka dari itu peneliti memulai tindakan penelitian pada siklus I.

\section{Siklus 1 \\ Tahap Perencanaan}

Pelaksanaan pembelajaran pada siklus I dilaksanakan sebanyak 2 kali pertemuan ( $2 x 40$ menit) pada pokok bahasan limit fungsi dengan topik menentukan nilai limit fungsi $\mathrm{f}(\mathrm{x})=0$. Sebelumnya, instrumen penelitian yang terdiri dari Lembar observasi kegiatan belajar siswa, lembar observasi kegiatan mengajar guru, RPP siklus I dan soal postest serta buku paket matematika yang menunjang dengan bahasan yang dimaksud telah disiapkan oleh peneliti. Proses pembelajaran pada RPP siklus I dengan menggunakan strategi pemecahan masalah Sistematis.

\section{Tahap Pelaksanaan}

Guru melakukan apersepsi kepada siswa dengan menanyakan materi sebelumnya dilanjutkan dengan pemberitahuan tentang materi yang akan dipelajari yaitu menentukan nilai limit fungsi $\mathrm{f}(\mathrm{x})=0$. Selanjutnya guru menulis di papan tulis mengenai hal-hal yang berkaitan dengan materi dan memberikan 2 butir contoh soal yang berbeda.

Kemudian guru membimbing siswa secara bertahap untuk melakukan analisis soal. Pada tahap analisis soal, pelaksanaannya masih belum sesui target, hal ini disebabkan siswa itu sendiri tidak tahu apa arti analisis dan cara melakukannya. namun, setelah dijelaskan guru mengenai analisis barulah sebagian siswa mengerti maksud dan tujuan serta pelaksanaannya. Selanjutnya guru membimbing siswa untuk melakukan transformasi soal dan siswa mengecek, apakah soalnya sudah berbentuk standar atau belum. rata-rata siswa yang mengerti hanya siswa yang memiliki kemampuan menengah ke atas karena siswa yang lain tidak begitu mengerti cara melaksanakannya dan hanya menunggu jawaban dari siswa yang paham.

Kemudian guru melakukan apersepsi kepada siswa dengan menanyakan materi sebelumnya, dilanjutkan dengan pemberitahuan tentang materi yang akan dipelajari yaitu menentukan nilai limit fungsi $\mathrm{f}(\mathrm{x})$ $=0$

Selanjutnya pada tahap melaksanakan rencana penyelesaian, yang dilakukan guru yaitu membimbing siswa melakukan operasi hitungan. Siswa mensubstitusikan data yang sudah diketahui ke dalam bentuk standar yang telah diperoleh, kemudian melakukan perhitungan. Dalam operasi hitungan, guru membimbing siswa dalam menghitung penyelesaian soal secara pelan-pelan dan bertahap.

Setelah selesai melakukan operasi hitungan, guru membimbing siswa melakukan pengecekan terhadap hasil penyelesaian soal misalnya mengecek apakah jawaban sudah sesuai dengan apa yang ditanyakan serta menelusuri kesalahan-kesalahan apa yang telah dilakukan.

\section{Observasi}

Observasi dilakukan dengan mengisi lembar observasi yang telah disediakan, yakni mengamati kegiatan guru dan siswa secara umum selama proses pembelajaran berlangsung. Dari beberapa keterangan yang terdapat pada lembar observasi guru, terdapat bahwa guru lupa menyampaikan tujuan pembelajaran dan motivasi, masih banyak siswa yang kurang memahami langkah-langkah strategi pemecahan masalah sistematis yang disebabkan guru tidak menjelaskannya. Selain itu, guru kurang tegas terhadap siswa yang tidak memperhatikan, bercerita dan bergurau dengan teman disekitarnya.

Sementara itu, pada tabel observasi siswa dapat diartikan bahwa siswa belum bisa beradaptasi dengan strategi pemecahan masalah sistematis, karena langkahlangkah strateginya tidak disampaikan gurunya dan perhatian guru tidak sepenuhnya terhadap siswa sehingga siswa yang tidak mengerti dan tidak diperhatikan malas belajar.

Dari hasil tindakan yang dilakukan pada siklus 1 dan dilakukan postest pada siklus 1 diperoleh hasil ada 13 siswa yang mencapai ketuntasan minimal. dari 20 orang siswa dengan rata-rata ketuntasan klasikal 69 atau dengan persentase ketuntasan klasikal baru mencapai $65 \%$.

Hasil ini belum mencapai target yang telah ditetapkan, maka proses pembelajaran dilanjutkan ke 
Hadiawati, Penerapan Strategi Pemecahan Masalah Sistematis (Systematic Approach to Problem Solving) untuk Meningkatkan Hasil Belajar Matematika Kelas XI IPS 2 SMA Negeri 1 Kerinci Tahun Pelajaran 2019/2020

siklus berikutnya dengan beberapa perbaikan berdasarkan kesalahan pada siklus I.

\section{Siklus II \\ Perencanaan}

Segala kekurangan pada siklus I telah didiskusikan observer dengan guru pelaksana penelitian, sesuai dengan kejadian pada refleksi siklus I. Diharapkan pelaksanaan tindakan siklus II lebih optimal dari tindakan siklus sebelumnya, sehingga target yang diinginkan dapat tercapai. Proses pembelajaran berdasarkan RPP siklus II yang telah disiapkan.

\section{Pelaksanaan}

Guru masuk ke kelas dengan mengucapkan salam dan dilanjutkan dengan do'a. Setelah selesai berdo'a, guru melihat karakteristik siswa apakah sudah siap untuk melanjutkan proses pembelajaran. Pada saat semua perhatian siswa tertuju kepada guru, guru memberitahukan ke siswa bahwa nilai hasil belajar mereka pada pertemuan yang telah lalu masih rendah , guru kembali membangkitkan motivasi belajar siswa, guru melakukan apersepsi dan menanyakan materi sebelumnya serta memberitahukan tentang materi yang akan dipelajari yaitu limit fungsi dengan topik Teorema Limit

Selanjutnya guru menulis materi pelajaran, memberikan 2 butir contoh soal yang berbeda di papan tulis, menyebutkan tujuan pembelajaran dan menjelaskannya. Kemudian guru membimbing siswa secara bertahap untuk melakukan analisis soal. Pada tahap analisis soal, pelaksanaannya lumayan bagus yang ditandai dengan semua perhatian siswa tertuju ke depan dan kebanyakan siswa melaksanakan apa yang diinstruksikan guru, sebagian siswa kurang paham dan mereka bertanya kepada guru serta menanyakan kepada teman disekitarnya dan mendiskusikannya.

Tahap selanjutnya adalah membimbing siswa melakukan rencana penyelesaian dan dilanjutkan dengan operasi hitungan. Dalam operasi hitungan, guru membimbing siswa dalam menghitung penyelesaian soal secara pelan-pelan dan bertahap, guru membimbing siswa melakukan pengecekan yang dimulai dari tahap analisis.

Selanjutnya siswa menyalin materi yang ada di papan tulis, setelah selesai menyalin dibuku catatannya mengenai materi yang didapat, kemudian guru memberikan 3 butir soal sebagai latihan untuk dikerjakan siswa sesuai dengan langkah-langkah strategi pemecahan masalah sistematis yang telah diterapkan oleh guru pada contoh soal sebelumnya, hal ini bertujuan untuk lebih memahirkan siswa dalam menyelesaikan soal- soal dengan menggunakan strategi pemecahan masalah sistematis yang telah didapat.

Semua siswa mengerjakan soal, guru mengunjungi siswa yang sering bercerita dan jarang memperhatikan ketika proses pembelajaran untuk dibimbing dalam menyelesaikan soal-soal latihan tersebut.

Siswa yang diperhatikan dan dibimbing oleh guru mengerjakan dengan serius dan mereka pun bangga ketika hasil kerja mereka sendiri benar dan dipuji oleh guru.

Dengan demikian, timbulah semangat mereka untuk mencari penyelesaian soal yang belum diselesaikan dan bahkan ada diantara mereka meminta kepada guru untuk menambahkan soal karena soal yang diberikan guru telah dijawab dan mereka yakin jawabannya benar.

Selain itu, siswa yang sudah memahami dan dikatakan mahir dalam menyelesaikan soal-soal yang diberikan guru pun ikut berpartisipasi membantu temantemannya yang kurang mengerti dan mendiskusikannya bersama-sama, suasana kelas tampak ribut akibat suara siswa-siswi yang berdiskusi.

Setelah selesai siswa menjawab soal latihan yang diberikan dan diperiksa oleh guru serta menyisakan waktu 15 menit, kembali guru melakukan postest untuk melihat hasil belajar matematika siswa selama 10 menit dan juga sebagai data peneliti pada siklus II.

Di akhir pembelajaran, guru dan siswa bersamasama meringkas atau menyampaikan intisari materi pelajaran mengenai limit fungsi dengan topik Teorema Limit.

Dari tindakan dan postest yang dilakukan pada siklus dua menunjukkan peningkatan yang signifikan dengan capai rata-rata ketuntasan mencapai 83 dengan persentase $85 \%$. Hal ini menunjukkan dengan menggunakan strategi pembelajaran dengan pemecahan masalah sistematis dapat meningkatkan hasil belajar siswa Kelas XI IPS 2 SMA Negeri 1 Kerinci.

\section{Observasi}

Selama pembelajaran berlangsung, observer mengamati perkembangan pembelajaran dan mencatat tindakan yang diamati melalui lembar pengamatan yang telah disediakan untuk guru dan siswa. Hasil observasi pada kegiatan guru menunjukkan peningkatan yang signifikan, karena hasil postest yang dilakukan siswa pada siklus II pun telah mencapai target bahkan lebih.. Pada siklus II, perhatian dan ketegasan guru terhadap siswa yang jarang memperhatikan sudah direspon bahkan guru lebih fokus membimbing siswa yang demikian. Sehingga hasil kuis yang mereka kerjakan mengalami peningkatan yang berarti.

Sementara itu, perhatian siswa terhadap guru saat proses pembelajaran berlangsung juga mengalami peningkatan. Salah satu penyebabnya adalah motivasi yang dilakukan guru sejak awal pembelajaran, sehingga siswa betul-betul serius untuk belajar. Walaupun masih ada juga siswa yang tidak memperhatikan, namun jumlahnya tidak sebanyak pada siklus I. Dari data hasil kuis belajar matematika yang dikerjakan siswa pada siklus II, terjadi peningkatan jika dibandingkan dari siklus sebelumnya. 


\section{Pembahasan}

\section{Pembelajaran Sebelum Tindakan}

Pembelajaran sebelum tindakan atau pembelajaran tanpa menggunakan strategi pemecahan masalah sistematis dilakukan guru jauh sebelum peneliti memulai penelitian. Adapun data hasil belajar matematika siswa pada penelitian adalah hasil pretest matematika yang dikerjakan siswa selama 10 menit sebelum masuk proses pembelajaran siklus I. Rata-rata hasil pretest yang dikerjakan siswa yaitu 44,85 atau persentase secara klasikal adalah $35 \%$.

\section{Pembelajaran Pada Siklus I}

Dari hasil postest siswa pada siklus I secara klasikal diperoleh rata-rata ketuntasannya sebesar 69 atau $65 \%$ artinya tumbuh sebesar $24,15 \%$ dari sebelumnya dengan rata-rata 44,85 atau $35 \%$ Namun, hasil tersebut belum mencapai target dan dilanjutkan pada siklus berikutnya.

\section{Pembelajaran Pada Siklus II}

Evaluasi terus dilakukan dan dilaksanakan dengan semaksimal mungkin, sehingga hasil belajar matematika siswa pada siklus II terjadi peningkatan yang drastis. Salah satu penyebabnya adalah ketegasan, perhatian dan bimbingan guru terhadap siswa lebih optimal. Adapun persentase hasil belajar matematika siswa secara klasikal pada siklus 2 adalah 83 atau $85 \%$ artinya tumbuh sebesar $14 \%$ dari siklus I dengan rata-rata 69 atau $65 \%$. Berdasarkan hasil persentase di atas, terjadi peningkatan hasil belajar matematika siswa dan telah mencapai target bahkan lebih, sehingga peneliti menghentikan penelitian ini.

\section{SIMPULAN}

Berdasarkan hasil penelitian dan pembahasan dapat disimpulkan bahwa penerapan model pembelajaran dengan pendekatan Strategi Pemecahan Masalah Sistematis pada mata pelajaran Matematika khususnya pada pokok bahasan Limit Fungsi dapat meningkatkan hasil belajar siswa kelas XI IPS 2 SMAN 1 Kerinci. Hal ini ditandai dengan meningkatnya nilai rata-rata hasil belajar siswa. Sebelum penerapan model pembelajaran dengan pendekatan Strategi Pemecahan Masalah Sistematis) nilai rata-rata ketuntasan belajar siswa sebelum adanya tindakan 44,85 atau 35\% dan setelah penerapan model pembelajaran dengan pendekatan Strategi Pemecahan Masalah Sistematis) pada siklus 1 naik menjadi 69 dengan ketuntasan klasikal $65 \%$. Pada Siklus II kemudian meningkat menjadi 83 dengan ketuntasan klasikal $85 \%$.

Berdasarkan hasil persentase di atas, terjadi peningkatan hasil belajar matematika siswa dan telah mencapai target bahkan lebih, sehingga peneliti menghentikan siklusnya dan disarankan kepada guru mata pelajaran matematika agar menggunakan model pembelajaran Strategi Pemecahan Masalah Sistematis sebagai salah satu solusi untuk mengatasi permasalahan dalam belajar matematika terutama pada materi Limit Fungsi Aljabar.

\section{DAFTAR PUSTAKA}

Abdurrahman, Mulyono, (2003), Pendidikan Bagi Anak Berkesulitan Belajar, Jakarta, Rhineka Cipta.

Ahmad Sabri, (2007) Strategi Belajar Mengajar Micro Teaching, Quantum Teaching, Ciputat

Made Wena, (2009). Strategi Pembelajaran Inovatif Kontemporer, Jakarta. Bumi Aksara

Mulyasa,(2004) Implementasi kurikulum, : Bandung : rosdakarya

Nana Sudjana, (2008) Penilaian Hasil Proses Belajar Mengajar, Remaja Rosdakarya: Bandung

Slameto (2003), Belajar dan faktor-faktor yang mempengaruhinya. Jakarta: Rineka Cipta

Wina Sanjaya, (2005). Pembelajaran dalam implementasi kurikulum berbasis kompetensi, Jakarta: Kencana 